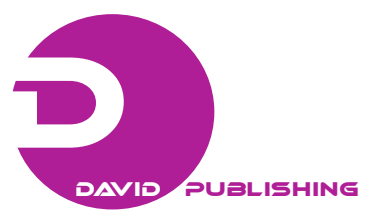

\title{
Effects of Contractual Savings Scheme on Slovak
}

\section{National Economy}

\author{
Július Golej and Miroslav Pánik \\ Institute of Management, Slovak University of Technology, Bratislava 81243, Slovak Republic
}

\begin{abstract}
Contractual savings scheme is specific purpose saving, which was provided in Slovakia since 1993. It is a state-supported saving, the purpose of which is to finance housing needs in the Slovak Republic. Savers can be an individual, association of owners or legal person who enters into a contract with building society or for whom the contract about contractual savings scheme is concluded. State bonuses is contractual savings scheme, a significantly more attractive form of targeted saving. This ensures the supply of investment in the construction sector, which in turn through multiplier effect significantly affects other sectors of the national economy. In this article, the authors deal with the influence of contractual savings scheme to the national economy of the Slovak Republic. The main objective of this study is describing the effectiveness of state bonuses for contractual savings scheme. It is simulated through the impact of contractual savings scheme on employment, on public funds and impact on public finances. This effect is illustrated on a model of state subsidizing of each one Euro spent through the state bonuses for contractual savings scheme and its impact for the national economy with offsetting the significant role of the multiplier effect.
\end{abstract}

Key words: National economy, contractual savings scheme, multiplier effect, housing sector, housing financing.

\section{Introduction}

Contractual savings scheme is, not only in Slovakia but also in Europe, one of the most frequent forms of housing financing. It creates conditions for the formation of equity and, through the participation of state, is one of the major sources of residential lending.

In its simplest form, a contractual savings for housing involves an agreement between a household and a financial institution regarding the granting of a loan at a future date dependent on successful fulfillment of a savings contract. The household agrees to save either a pre-specified total or a certain minimum amount each year. At the end of the savings period, the household becomes eligible for a loan the amount of which is dependent on the amount saved [1]. Contractual savings scheme is an important source of financing for development and maintenance of housing stock in the Slovak Republic. It has a

Corresponding author: Július Golej, Ph.D., research fields: real estate development process, land management and real estate market. E-mail: julius.golej@stuba.sk. positive impact on housing demand and supply thanks to the provision of accessible housing credits, indirectly supported by the state premium [2]. It supports targeted saving of the population while the vast majority of investment goes to housing and it is also a major source of residential lending for the Slovak population. Investments from construction savings encourage the employment growth and production in the housing sector, development of human settlements, employment, consumer expenditures in other economic sectors and grants and revenues to the state budget as well.

Accumulation of funds by construction savings scheme influences the expenditure structure of the population. Citizens spend more money on construction works which are mostly carried out by using domestic materials and home workers. Less money will then remain for some commodities, such as luxury goods imported from abroad or foreign holidays, which are indeed a source of job creation outside of Slovakia, but for Slovakia it means increase of unemployment and foreign trade deficit. It also 
means less money spent on alcohol and cigarettes and on excise tax, which some economists welcome as a source of state budget income but they forget to calculate with the impact of these expenditures on working disablement, medical expenses and loss of productivity. In this sense, investment in housing sector is acting anti-inflationary.

Contractual savings scheme in Slovakia is covered by the Law No. 310/1992 Collection of Laws about contractual savings scheme as amended. Under that law contractual savings scheme may be provided with permission only by special banks-building societies. Slovakia currently has three building societies. Compliance with the conditions in state bonuses is realized by state supervision of the Ministry of Finance of the Slovak Republic. This Ministry also provides the central register of saving contracts.

The authors in this study also take into account the presumption of cancellation of state bonuses (which the government was considering in 2011) and its consequent impact on the economy. Such a move would lead to significant losses in the areas of tax collection, contributions to insurance companies, job losses and increased costs due to unemployment. Under the conditions of high unemployment and the government deficit in Slovakia, it represents, in authors' opinion, the high political risk. In addition, the shortfall caused by the investment would bring negative consequences by slowing the flow of funds into housing sector (for insulation and reconstruction of housing stock) which may adversely affect the amount of greenhouse gas emissions in the energy balance of the state, and thereby, negatively influence the direction of economic growth based on sustainable development.

\section{State Expenditures Associated with the Contractual Savings Scheme}

The government supports construction savings through a state support in the form of bonuses. State bonuses represent a percentage of the annual contractual saving deposit of saver and the calculation of this percentage is established in Contractual Savings Scheme Act in 1993. The Ministry of Finance by its actions annually announces the amount of state bonus for the following calendar year. State bonuses may be granted only for one personal entity-saver or for legal entity-saver (an owners' association). The maximum amount of a state bonus is provided by law.

Average volume of annual state premium for $\mathrm{CSH}$ (contractual savings scheme for housing) reimbursed by state budget during the period from 2008 to 2011 represented $€ 41$ million, from which benefitted 963,000 savers on average (Table 1).

\section{Multiplier Effect and Calculation of Multiplier}

The construction industry as a sector affects the production in almost all other sectors of national economy. It has a significant impact on employment in primary (building) industry but also it affects employment throughout the whole economy. The intensity of this impact is measured by the multiplier effect. This effect determines size of investments or new job opportunities caused by activities in primary sector, for example in construction industry or in other sectors of national economy.

The coefficient of multiplier effect of various construction activities in the world ranges from 1.8 to 3.5, while in the sector of housing construction it is generally higher. For example in the year 1977-1993,

Table 1 The number of savers and the volume of state premium of CSH provided by state budget to savers during the period 2008-2011.

\begin{tabular}{lllll}
\hline Year & 2008 & 2009 & 2010 & 2011 \\
\hline Number of savers & 929,696 & 973,264 & 973,318 & 962,730 \\
The amount of state premium (in $€$ ) & $38,578,000$ & $43,620,000$ & $41,610,000$ & $43,100,000$ \\
\hline
\end{tabular}

Source: contractual savings banks/The Ministry of Finance of the Slovak Republic [3]. 
the multiplier effect of housing construction in Poland ranged from 2.4 to 2.7. This means that the increase of employment in the construction sector has led to a 1.4 to 1.7 multiple increase of employment in other sectors of national economy [4]. In the Czech Republic in 2000, this coefficient reached a value 2.6. ISI EMERGING Markets (Investment Information Emerging Markets) [5] argues that the employment multiplier in the construction sector usually stands from 3.2 to 3.5 .

Our calculations of the coefficient of multiplier effect was based on the matrix of cross-sectorial flows from the year 2008 (with revision in 2011) which has size $85 \times 85$ sectors. According to methodology of a NACE (classification of economic activities SK (Slovakia)) - in 41st up to 43rd line, there is the construction industry with the following structure: the 41 line - buildings and construction of buildings; the 42 line-structures and construction of engineering structures; the 43 line-specialized construction works.

Within the context of input-output analysis, we calculated that the value of the multiplier for Sector 41 "buildings and construction of buildings" are $L=2.85$. This means that increasing in production in this sector-"buildings and construction of buildings" by one unit, causes increasing of the total production in all sectors by 2.85 units (see Appendix).

\section{The Benefits of Contractual Savings Scheme to the National Economy of the Slovak Republic}

The benefits of contractual savings scheme can be generally divided into three areas:

- benefits for employment;

- savings of public funds as a result of higher employment;

- impact on public finances.

\subsection{Benefits for Employment}

In 2010, the sum of housing investments from all three building societies was $€ 392.6$ million. The amount of investment flowing into the housing from three building societies that year represented $64 \%$ of all funds provided by savings banks. These investments were used for various purposes as follows:

- reconstruction-€255 million;

- purchase- $€ 112$ million;

- new construction - $€ 26$ million.

Since the total construction output-subsectors "buildings and construction of buildings" was, in 2010, $€ 1,302$ million [6] and labor productivity amounted to $€ 26,856$ per employee, it provided approximately 50,000 new job opportunities for employees. Contractual savings scheme participated on these investments by $€ 392.6$ million. With labor productivity per employee $(€ 26,856)$, contractual savings scheme has participated in the creation almost 14,760 new jobs in the subsector "buildings and construction of buildings". By offsetting of the multiplier effect $(L=2.85)$, this leads to the creation of approximately 42,060 jobs throughout the whole economy. These jobs already involves 14,760 jobs in the construction subsector "buildings and construction of buildings" and 27,300 jobs in all other sectors of national economy (including other construction subsectors or subclasses). This impact on job creation in the economy is definitely not negligible.

\subsection{Savings of Public Funds as a Result of Higher Employment}

Unemployed citizens do not pay income taxes, moreover, they generate state budget expenditures in the form of levies and contributions to social and health insurance. The growth of unemployment is creating a very strong pressure on public finances. In this section, costs are calculated for unemployed person, which arises to the state in the case of non-creating jobs through the contractual savings scheme.

Estimation of social benefits provided to one 
unemployed person in Slovak national economy.

The state expenditures in the form of various social benefits for a one unemployed person in 2010 over 6 months consisted of:

- average biannual support of $€ 1,544.16$ (average monthly unemployment compensation in 2010 represented €257.36) [7];

- health insurance (4\%), i.e., €184.56 (calculated from the average gross wage in Slovak economy in 2010 represented €769) [7].

The state benefits provided to one unemployed person over the 6 months represented approximately $€ 1,730$ in 2010 .

If a one unemployed person has worked instead of receiving the unemployment compensation (during six months), it would bring the state budget an average of $€ 809$ per year. This amount consists of contributions to social insurance company of $€ 432$ and from a wage tax of $€ 377$. Therefore, the total expenditure for a state per one unemployed person in 2010 represented approximately $€ 2,540$.

In our considerations, we have not taken into account other possible state expenditures in 2010 and active employment policy which is difficult to quantify (contribution for establishment of the small business, commuting contribution for the distant job places, state contribution for supporting the job mobility, retraining, etc.).

If contractual savings scheme was not a source of significant investment in housing, then the state would lose totally €97.4 million throughout the national economy as a result of growing unemployment in 2010 .

\subsection{Impact on Public Finances}

Taxes are the most important revenue item of the state budget, which serve to cover the state budget expenditure. The tax system is the sum of taxes levied in the country in a given period. Its mission is to provide revenues to cover all necessary expenses of the state. Tax system in Slovakia consists of direct taxes (paid by operators for each of their income or assets and transfer them directly) and indirect taxes (paid by actors in the price of goods or services, but diverting them through another person, i.e., indirectly) [8].

The most important benefits of contractual savings scheme for public funding are:

- income to the state budget from VAT (value added tax);

- income to the state budget from income tax;

- contributions to health and social insurance.

\subsection{Value Added Tax}

Taking into account the assumption that all investments from contractual savings scheme have been spent in Slovakia, it can be argued that the entire volume of these investments was in the end paid VAT of $19 \%$.

If we use the fact that investments from construction savings in 2010 was $€ 392.6$ million and the rate of VAT was $19 \%$, then the total amount of income to the state budget from VAT was $€ 74.6$ million. In this case, we did not consider the possibility of spending these investments from contractual savings scheme abroad, since we cannot accurately map the financial flows of these investments.

\subsection{Income Tax and Contributions to Health and Social Insurance}

Income tax is one of the direct taxes. In 2010, income tax burden was 19\%. The employee pays from wages in addition to income tax also levies which are other important contributions to the economy of the state. Contributions can be divided into two groups: social contributions and contributions to health insurance.

The employer is also obliged to contribute to social and health insurance of his employees. Monthly contributions in 2010 for health insurance were $4 \%$ of gross wage, $1.4 \%$ of gross wage for health insurance, 
$4 \%$ of insurance for retirement pension, $3 \%$ for the disability pension insurance and $1 \%$ for unemployment insurance of gross wage. Employees do not pay charges for accident insurance, guarantee insurance and reserve fund. Total employee contributions to health and social insurance represent $13.4 \%$ of monthly gross income [9].

The employer pays the employee's monthly health insurance of $10 \%$ of super-gross wage, $1.4 \%$ for health insurance, retirement pension to $14 \%$, the disability pension of $3 \%, 0.8 \%$ of accident insurance, unemployment insurance $1 \%$, guarantee insurance of $0.25 \%$ and for the reserve fund of solidarity of $4.75 \%$ of super-gross wage. The employer and the employee pay their monthly $35.2 \%$. Total employer contributions to health and social insurance of employee are $35.2 \%$ of monthly super-gross wage.

In 2010, investments from contractual savings scheme generated 14,700 jobs in the subsector "buildings and construction of buildings". We estimate, according to the yearbook of the Slovak construction industry of 2011 , that 2,900 jobs were created in large companies, 2,400 jobs in small businesses and about 9,400 jobs were accounted for tradesmen [10]. Knowledge of this structure is important because the average amount of taxes and contributions from wages varies within this business division. According to calculations, we came to the result that the total amount of taxes and contributions from wages of employees in small and large businesses and from wages of tradesmen in the construction sector in subsector "buildings and construction of buildings" in 2010 was $€ 38.1$ million.

Considering the multiplier effect that generates in the economy, about 27,300 jobs and the average wage in the economy at level $€ 769$ in 2010 , the tax revenue after taxing the employees reached $€ 10.3$ million and contributions collected reached $€ 122.4$ million. Total revenue from taxes and contributions from workers throughout the whole economy was $€ 132.7$ million.

The total addition from the investment from contractual savings scheme for the national economy of Slovak Republic in the form of tax and contribution revenues to insurance in 2010 represented $€ 245.4$ million (Table 2).

\section{Conclusions}

Support of contractual savings scheme by a state premium has significant impact on the development of housing sector and for the Slovak economy as a whole.

Table 2 Effects of contractual savings scheme on Slovak national economy in 2010.

\begin{tabular}{ll}
\hline The effect of construction savings for the national economy of Slovakia & \\
\hline MP (multiplier effect) in entire economy & 2.85 \\
MP in construction & 1.0 \\
MP in other sectors & 42,060 \\
\hline Job creation & 14,760 \\
\hline Overall & 27,300 \\
Construction & $€ 245,400,000$ \\
Other sectors & $€ 88,050,000$ \\
\hline Benefits for national economy & $€ 157,350,000$ \\
\hline Total & $€ 97,400,000$ \\
From taxes & $€ 342,800,000$ \\
From contributions to insurance & $€ 41,610,000$ \\
\hline State budget savings & $€ 8.2$ \\
\hline Overall for unemployed & \\
\hline Benefits of construction savings for national economy and state budget & \\
\hline Overall benefit in 2010 & \\
Costs for the state bonus in 2010 & \\
$€ 1$ of state premium to the contractual savings scheme brings to the state budget & \\
\hline
\end{tabular}


State expenditures on these savings are repayable and in form of multiplier effect, they also influence the development of other industries.

The overall efficiency of the unit of state bonus $(€ 1)$ can be expressed from the results above through its share to the total contribution of investment for the national economy caused by contractual savings scheme. The total benefit is the sum of revenues from taxes, contributions from individuals and legal entities, government resource savings for supporting unemployment and contributions to insurance companies according to model scenario of not creating job opportunities through investments from contractual savings scheme. Based on the obtained results, we can conclude that every $€ 1$ of state bonus going to contractual savings scheme generated more than 8 times higher amount in the national economy in 2010 (Table 2).

Contractual savings scheme is also a supportive method of funding housing for poor regions of Slovakia since, in these regions, the citizens often do not fulfill the conditions for getting other loans to obtain adequate housing. Contractual savings scheme is a support tool for mitigation of regional disparities. Investments into thermal insulation have positive impact on energy savings, which are very important at a time when energy prices are growing rapidly.

\section{Acknowledgments}

This paper is supported by grant under the program to support for young researchers 2013 (ENAPUR (Economic instruments and law in land development process) and CNDFDP (Real estate prices as a determinant factor of the demographic potential and economic activity of population in Slovak republic)) and by grant VEGA (Slovak Scientific Grant Agency) No. 1/1013/12 "Economic aspects of energy savings in buildings".

\section{References}

[1] M.J. Lea, B. Renaud, Contractual Savings for Housing:
How Suitable Are They for Transitional Economies, World Bank Publications, 1995.

[2] D. Špirková, K. Ivanička, M. Finka, Housing and Housing Policy: Development, Determinants of Housing Development and New Approaches to Rental Housing Policies in Slovakia, Nakladatel'stvo STU (Publishing house of Slovak University of Technology), Bratislava, 2009.

[3] Contractual Savings Banks, Prvá stavebná sporitel’ňa, a.s. (First building and loan association Inc.), Wüstenrot stavebná sporitel'ňa, a. s. (Wüstenrot building and loan association Inc.), ČSOB Stavebná sporitel'ňa, a.s. (ČSOB (Czechoslovak commercial bank) building and loan association Inc.), The Ministry of Finance of the Slovak Republic, 2011. (in Slovak)

[4] W. Korecki, W. Rydzik, L. Kalkowski, Zwiazki budownictwa mieszkaniowego $\mathrm{z}$ gospodarka narodowa. Instytut gospodarki mieszkaniowej (Relationships of Housing and the National Economy), Institute of Housing, Warszawa, 1994. (in Polish)

[5] V roce 2010 propad nekončí Asociacie PPP. 20.10.2010 (In 2010, the decline does not stop, the PPP (Public Private Partnership) Association) (According to ISI EMERGING markets), [Online], http://www.asociac eppp.cz/?action=ventire\&n_id $=1187 \&$ page $=2 \&$ nonotify $=$ 0 (accessed Dec. 19, 2013). (in Czech)

[6] Input-Output Tables, Statistical Office of the Slovak Republic, 2008.

[7] Central Office of Labour, Social Affairs and Family [Online], http://www.upsvar.sk/urady-psvr.html?page_ id=215\&lang=en (accessed Dec. 14, 2013).

[8] A. Suhányiová, M. Petrišová, The Tax System of the Slovak Republic with an Emphasis on Value Added Tax [Online], 2011, http://www.pulib.sk/elpub2/FM/Kotulic 14/pdf_doc/20.pdf (accessed Dec. 16, 2013).

[9] Social Insurance Agency in Slovakia [Online], http://www.socpoist.sk/?lang=en (accessed Nov. 12, 2013).

[10] Ročenka slovenského stavebníctva 2011 (Yearbook of the Slovak Construction Industry of 2011) [Online], Ministry of Transport, Construction and Regional Development, 2011, http://www.telecom.gov.sk/index/ index.php?ids=84674 (accessed Nov. 12, 2013).

[11] W.W. Leontief, Input-Output Economics, 2nd ed., Oxford University Press, 1986.

[12] J. Husár, V. Mokrášová, M. Goga, Input-output analýza a systém národných účtov (Input-output analysis and the system of national accounts), Vydavatel'stvo Ekonóm, 2007. (in Slovak)

[13] R. Pietrofortea, T. Gregorib, An input-output analysis of the construction sector in highly developed economies, Journal of Construction Management and Economics 21 
(3) (2003) 319-327.

[14] W.W. Leontief, The Structure of American Economy, 1919-1929, 2nd ed., Oxford University Press, NY, 1951.

[15] M. Rojíček, Klíčová odvětví v české ekonomice $\mathrm{Z}$ pohledu input-output analýzy, (Key sectors of the Czech economy in terms of input-output analysis), Statistics 2 (2007) 133-145 [Online], http://panda.hyperlink.cz/cesta pdf/pdf07c2/rojicek.pdf (accessed Dec. 10, 2013). (in Czech)

\section{Appendix}

In our analysis, we used the following calculations of multiplier coefficient.

To calculate the multiplier, knowledge from input-output analysis [11] was used. The starting point of input-output model is input-output table, respectively, commodity-sectorial table that shows the relationships between sectors of the national economy and quantitative flows of production in the productive and non-productive sphere [12]. Analysis focuses also on technologies, with emphasis on the relative role of manufacturing and services inputs. Lastly, standard measures of linkages are used to determine the main sources of induced output that are created by the push and pull effects of the construction sector on the rest of the economy [13].

Input-output table consists of four quadrants that show cross-sectorial flows, components of final consumption, total production and added value in individual sectors of the economy.

To calculate the multiplier, it was necessary to analyze the first quadrant of input-output table, which shows the relationship between economic sectors-cross-sectorial flows, so-called intermediate consumption. The matrix of intermediate consumption indicates how many units of production of one economic sector were used within the productive consumption in other sectors of the national economy.

The matrix of intermediate consumption $\boldsymbol{X}$ is square shape with dimensions $n \times n$, while lines from " 1 ", "2" to " $i$ " until to " $n$ " indicate the supplier sector and columns " 1 ", " 2 " to " $i$ " until to " $n$ " indicate the consumer sector. Element " $x_{i j}$ " indicates the volume of consumption of production of the " $i$ " sector in the " $j$ " sector.

$$
\boldsymbol{X}=\left[\begin{array}{ccccc}
x_{11} & \cdots & x_{1 j} & \cdots & x_{1 n} \\
\vdots & \ddots & \vdots & & \vdots \\
x_{i 1} & \cdots & x_{i j} & \cdots & x_{i n} \\
\vdots & & \vdots & \ddots & \vdots \\
x_{n 1} & \cdots & x_{n j} & \cdots & x_{n n}
\end{array}\right],(i, j=1,2, \cdots n)
$$

Relations between the different sectors are very strong, because the changes in the volume of certain sector affect the flows of production in all of its supply sectors. This is reflected in the production of these sectors.

Consumption of production of the " $i$ " sector in the production of the " $j$ " sector " $x_{i j}$ " is a function of the total production of this sector " $x_{j}$ " which can be expressed by the following equation [12]:

$$
x_{i j}=f_{i j}\left(x_{j}\right),(i, j=1,2, \cdots n) .
$$

Provided that:

- The character of functions " $f_{i j}$ " is the same for all sectors of production;

- In the production, outputs are used the same technological process;

- Consumption of individual products in the output production is directly proportional to the scale of produced production;

- Production factors are consumed in fixed ratio.

Consumption of production of the " $i$ " sector in the production of the " $j$ " sector " $x_{i j}$ " can be expressed as a linear function " $x_{j}$ " by using the Leontief production function [14]:

$$
x_{i j}=a_{i j} \cdot x_{j},(i, j=1,2, \cdots n) .
$$

After the treatment, we receive technological coefficients or direct consumption coefficients expressing the financial volume of 
production of the "i" sector supplied to total production per unit of the " $j$ " sector [12].

$$
a_{i j}=\frac{x_{i j}}{x_{j}},(i, j=1,2, \cdots n) .
$$

Coefficients of direct consumption for all sectors can be written by the matrix $\boldsymbol{A}$ :

$$
\boldsymbol{A}=\left[\begin{array}{ccccc}
a_{11} & \cdots & a_{1 j} & \cdots & a_{1 n} \\
\vdots & \ddots & \vdots & & \vdots \\
a_{i 1} & \cdots & a_{i j} & \cdots & a_{i n} \\
\vdots & & \vdots & \ddots & \vdots \\
a_{n 1} & \cdots & a_{n j} & \cdots & a_{n n}
\end{array}\right],(i, j=1,2, \cdots n)
$$

The total output of sectors expresses a column vector $\boldsymbol{X}$ :

$$
\boldsymbol{X}=\left[\begin{array}{l}
x_{1} \\
\vdots \\
x_{i} \\
\vdots \\
x_{n}
\end{array}\right](i=1,2, \cdots n)
$$

Husár et al. [12] show the relationship how to calculate complex coefficients of consumption, which reflect necessary extent of production in the " $i$ " sector, needed to produce one unit of output in the " $j$ " sector for final consumption:

$$
\boldsymbol{L}=(\boldsymbol{I}-\boldsymbol{A})^{-1}
$$

where, $\boldsymbol{I}$ is the unitary matrix of size $n \times n$ :

$$
\boldsymbol{I}=\left[\begin{array}{ccccc}
1 & \cdots & 0 & \cdots & 0 \\
\vdots & \ddots & \vdots & & \vdots \\
0 & \cdots & 1 & \cdots & 0 \\
\vdots & & \vdots & \ddots & \vdots \\
0 & \cdots & 0 & \cdots & 1
\end{array}\right]
$$

The $\boldsymbol{L}$ is the inverse matrix $(\boldsymbol{I}-\boldsymbol{A})^{-1}$ with elements " $l_{i j}$ ":

$$
\boldsymbol{L}=\left[\begin{array}{ccccc}
l_{11} & \cdots & l_{1 j} & \cdots & l_{1 n} \\
\vdots & \ddots & \vdots & & \vdots \\
l_{i 1} & \cdots & l_{i j} & \cdots & l_{i n} \\
\vdots & & \vdots & \ddots & \vdots \\
l_{n 1} & \cdots & l_{n j} & \cdots & l_{n n}
\end{array}\right],(i, j=1,2, \cdots n) .
$$

The matrix $\boldsymbol{L}$ is called the matrix multiplier which transforms changes in final consumption to changes in production [12].

The multiplier of particular sector is obtained by summing of multipliers per individual sector (sum of line). If final production of the sector increases by one unit, the total production in all other sectors will increase exactly by the value of the multiplier [15]. 